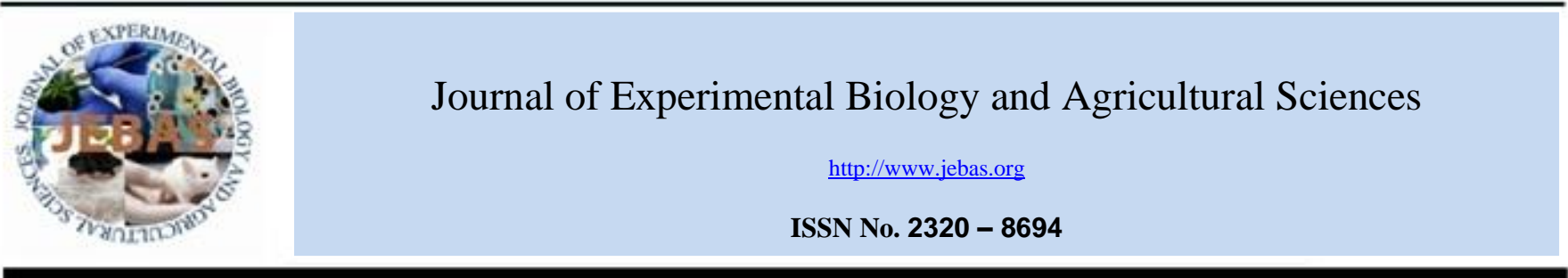

\title{
EFFECT OF TEXTILE WASTEWATER IRRIGATION ON SOIL PROPERTIES IN WESTERN RAJASTHAN
}

\author{
Shellina Khan, Navneet Joshi* \\ Department of Biosciences, Mody University of Science and Technology, Lakshmangarh, 332311, Sikar, Rajasthan, India
}

Received - August 16, 2019; Revision - October 01 , 2019; Accepted - October 04, 2019

Available Online - October 15, 2019

DOI: http://dx.doi.org/10.18006/2019.7(5).489.493

\author{
KEYWORDS \\ Physico-chemical properties \\ Textile industries \\ Agriculture \\ Effluents \\ Soil
}

\begin{abstract}
The current research is focused on the evaluation of physico-chemical properties of soil. Textile industries of Jodhpur and Balotra cities of Western Rajasthan discharge plenty of pollutants that get mixed up with water bodies. These water bodies are basically the parts of Jojari and Luni Rivers. The soil sites near to the end points or nearby points of these rivers became polluted due to mixing of industrial effluents coming from textile industries located nearby these rivers. When same wastewater is used for irrigation it adversely affects the soil properties. Thus the analysis of soil became an apparent need for best agriculture practices. Results of current study analysis revealed significant variance in the values of the parameters like $\mathrm{pH}, \mathrm{EC}, \mathrm{CEC}$ and $\mathrm{OC}$ from the range of standard values set by IS: 24901982 for industries. The N (275.8-387 mg/100g), P (51.2-115.4 kg/ha) and K (378-756 kg/ha) amount was also found very high in soil samples compared with IS values. Hence, it can be conclude that the concentration of effluents affects the soil quality. Therefore, monitoring of physico-chemical properties of soil are required for better crop production.
\end{abstract}

* Corresponding author

E-mail: navybiotech@gmail.com (Navneet Joshi)

Peer review under responsibility of Journal of Experimental Biology and Agricultural Sciences.

Production and Hosting by Horizon Publisher India [HPI] (http://www.horizonpublisherindia.in/).

All rights reserved.
All the articles published by Journal of Experimental Biology and Agricultural Sciences are licensed under a Creative Commons Attribution-NonCommercial 4.0 International License Based on a work at www.jebas.org.

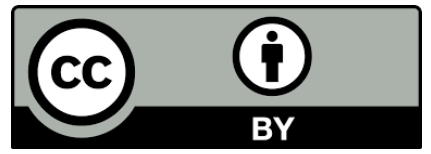




\section{Introduction}

Soil plays a significant role in growth of plants sustaining the biome with its natural flora, fauna and indirectly endures the environs. In the present providence, several kinds of operations involving transportation, agriculture and industry create the large volume of trashes and novel soil pollutants (Hossain et al., 2014). In terms of the amount and structure, the textile handling effluent is noted as ultimate pollutant out of total industrial regions (Anjaneyulu et al., 2005). At many places of world including India this textile effluents disposed in nallah or rivers are directly utilized for agriculture practices (Hossain et al., 2014). When such water used for irrigation, increases the level of soil contamination.

The United States Environmental Protection Agency stated that the effluent released from different textile industries may vary in composition according to their source of production. This textile effluent not only contains the toxic substances but it also has some essential nutrients (Chhonkar et al., 2000). Micronutrients are essential nutrients which required in very small quantities for normal plant growth but in textile effluents concentration of these micronutrients became higher due to continuous accumulation of dyes and other reagent (Meena \& Mathur, 2017). The lesser availability of agricultural water in Rajasthan forced farmer to use wastewater for irrigation. Essential macro and micronutrient present in effluent may increases the soil fertility but due to the presence of higher concentration of toxic substances it may reduces the soil fertility and adversely affects the nearby agricultural lands (Chhonkar et al., 2000). Further presence of higher concentration of pollutants also changed quality of water which does not support the best agricultural yield (Hossain et al., 2014). Effluents from the textile industries not only manipulate the surface water quality but also affect the underground water and soil productivity. Further, continuous uses of this type of water for irrigation changes the physicochemical properties of soil which affects the agricultural productivity (Hossain et al., 2014). Also improper nutrient management has led to emergence of multinutrient deficiencies in the soils (Meena \& Mathur, 2017). Hence, concern over the sustainability of environment, the present study was aimed to determine the physico-chemical parameters of industrial wastewater contaminated soil.

\section{Materials and Methods}

\subsection{Study area}

The study areas selected for the present research are located in the Western part of Rajasthan, India. The Salawas and Sangariya village of Jodhpur district situated near the Jojari
River are highly polluted area as of established textile industries. Jojari River is lying between $26^{\circ} 07^{\prime} 39.7^{\prime \prime}$ north latitude to $72^{\circ} 59^{\prime} 05.9^{\prime \prime}$ east longitude in Jodhpur district while the site of Luni River is located from $25^{\circ} 50^{\prime} 07.4^{\prime \prime}$ north latitude to $72^{\circ} 12^{\prime} 30.7^{\prime \prime} \mathrm{E}$ longitude in Barmer district of Rajasthan India. Similarly, RIICO at Balotra, Barmer, Rajasthan, India has become the industrial state (Meena \& Nama, 2016). Textile industries located in the above said areas discharge pollutants in Jojari and Luni Rivers and other water bodies. This wastewater when used for irrigation affects the quality of the soil of the surrounding area. Study sites are abbreviated as S1(Dangiyawas Bypass, Sangariya Village, Jodhpur), S2 (Jojari River, Boranada-Salawas Road, Jodhpur), S3 (Dumping Area, RIICO Complex, Balotra) and S4 (Waste treatment Plant, E-240, $3^{\text {rd }}$ Phase Industrial Area, Balotra).

\subsection{Sample Collection}

The soil samples were collected from the above mentioned selected sites (S1-S4) with the help of hand trowel in plastic bags . These samples were dried in oven for 4-5 hours at temperature $50^{\circ}$ C. The samples were analyzed for Physico-chemical properties using standard procedures.

\subsection{Chemical Analysis}

Collected soil samples were analyzed by studying various parameters like total Phosphorus $\left(\mathrm{P}_{2} \mathrm{O}_{5}\right)$, Nitrogen $(\mathrm{N})$, Organic Carbon, Potassium $\left(\mathrm{K}_{2} \mathrm{O}\right)$, Magnesium $\left(\mathrm{Mg}^{2+}\right)$ (Versanate EDTA method), Calcium $\left(\mathrm{Ca}^{2+}\right)$, Carbonate $\left(\mathrm{HCO}_{3}{ }^{-}\right)$, Phosphate $\left(\mathrm{PO}_{4}^{-}\right)$, Nitrate $\left(\mathrm{NO}_{3}\right)$. The $\mathrm{pH}$ and electrical conductivity were determined by the standard method given by Edori \& Iyama (2017). Further, Okoye \&Agbo (2011) method was used to estimate nitrates and chlorides concentration. The $\mathrm{P}_{2} \mathrm{O}_{5}$ was determined by the Olsen's method (Libutti et al., 2018) and Walkley-Black Method was used to estimate TOC \% in soil samples (Libutti et al., 2018). Nitrogen was determined by Kjeldahl method (Reeuwijk, 2002). Similarly, CEC was estimated by ammonium acetate method (Reeuwijk, 2002).

\section{Results and Discussion}

Available literature from national and international repositories suggested that textile industry of study areas discharged unprocessed wastewater directly into the main drainage network which further released into the sample collection areas. Results presented in table 1 revealed various physico-chemical properties of contaminated soils at different sampling sites. These results were further compared with standard values. The overall nutrient availability in study area soil were found very high as compared to the standard soil nutrient value, this might be because of large amount of effluents discharged from the textile industries. 
Table 1: Physico-chemical properties of contaminated soil samples from different sites

\begin{tabular}{|clccccc|}
\hline S.No. & $\begin{array}{l}\text { Sites } \\
\text { Properties }\end{array}$ & $\mathrm{S} 1$ & $\mathrm{~S} 2$ & $\mathrm{~S} 3$ & S4 & $\begin{array}{c}\text { IS:2490- } \\
1982 \text { Values }\end{array}$ \\
\hline 1. & $\mathrm{pH}$ & 8.91 & 8.65 & 8.00 & 8.80 & $8.5-9.5$ \\
\hline 2. & $\mathrm{EC}\left(\mathrm{dSm}{ }^{-1}\right)$ & 0.828 & 1.30 & 0.776 & 12.0 & $1.5-3.0$ \\
\hline 3. & CEC $(\mathrm{meq} / 100 \mathrm{~g})$ & 3.87 & 3.79 & 3.70 & 3.58 & $3.5-4.0$ \\
\hline 4. & Organic $\mathrm{C}(\%)$ & 0.180 & 0.195 & 0.300 & 0.195 & $0.5-0.75$ \\
\hline 5. & Nitrogen $(\mathrm{N})(\mathrm{mg} / 100 \mathrm{~g})$ & 289.5 & 275.8 & 296.7 & 387.0 & $180-207$ \\
\hline 6. & Phosphorus $\left(\mathrm{P}_{2} \mathrm{O}_{5}\right)(\mathrm{kg} / \mathrm{ha})$ & 51.29 & 57.50 & 53.86 & 115.41 & $23.0-56.0$ \\
\hline 7. & $\begin{array}{l}\text { Potassium }\left(\mathrm{K}_{2} \mathrm{O}\right) \\
\text { (kg/ha) }\end{array}$ & 378.0 & 580.5 & 243.0 & 756.0 & $144-336$ \\
\hline 8. & Calcium $(\mathrm{meq} / 100 \mathrm{~g})$ & 0.168 & 0.161 & 0.160 & 0.152 & $>0.10$ \\
\hline 9. & Manganese $(\mathrm{meq} / 100 \mathrm{~g})$ & 0.110 & 0.095 & 0.091 & 0.087 & $>0.1$ \\
\hline
\end{tabular}

Here S1-(Dangiyawas Bypass, Sangariya Village, Jodhpur), S2 (Jojari River, Boranada-Salawas Road, Jodhpur), S3 (Dumping Area, RIICO Complex, Balotra) and S4 (Waste treatment Plant, E-240, $3^{\text {rd }}$ Phase Industrial Area, Balotra); The resultant values were out sourced and analyzed by RSPCB Laboratory, Jodhpur with standard protocols and readings are average values.

\subsection{Electrical Conductivity and pH}

The soil $\mathrm{pH}$ was recorded alkaline in all the samples collected from study areas. The $\mathrm{pH}$ of effluent contaminated soil was ranging between 8.0-8.9. Although this range is in limitation of better crop growth but slightly higher than standard value. There are many views associated with effects of long-term wastewater application on soil $\mathrm{pH}$. Previous studies also confirmed the higher soil $\mathrm{pH}$ values in soil irrigated with wastewater (Kaur \& Sharma, 2014). Further, electrical conductivity (EC) of contaminated soil has higher variation than standard one. EC values of the affected soil increased by the increasing concentration of chemical salts released from the textile industries. Further, in contaminated soil, higher concentration of cations led to increase in EC. Sample collected from $3^{\text {rd }}$ Phase of Industrial Area in Balotra (S4) have higher EC value as compared to IS: 2490-1982 recommendation while the rest of the sample collected from the other three sites were found to have very lower EC value.

\subsection{Cation Exchange Capacity (CEC) and Organic carbon (OC)}

CEC was found in the range of Indian Standard value of all samples (Table 1) while reading of OC were recorded very less than IS: 2490-1982 (Table 1). The variation in OC content is due to long term irrigation of wastewater in soil (Kaur \& Sharma, 2014). Generally, the CEC value increase with increase in organic contents and pH. Jolly et al. (2012) reported a reduction in CEC value due to presence of humus and clay in the effluent.

\subsection{Nitrogen, Phosphorus and Potassium}

Nitrogen is an essential macronutrient required for stimulating plant growth. It is an important constituent of all fertilizer formulations. The textile wastewater also contains variable amount of nitrogen as nitrate, ammonia, organic nitrogen or nitrite. Samples investigated in present study contained higher values of total $\mathrm{N}(275.8-387 \mathrm{mg} / 100 \mathrm{~g})$ than IS values (Table 1).The similar results for the total nitrogen were reported by Hossain et al. (2014). Thus its mixing in the soil increases the plant productivity directly but raises the level of toxicity too (Hossain et al., 2014).

Phosphorus is also a major macronutrient for the growth of the plant but excess amounts of phosphorus enhances the formation of algal blooms in water and depresses the soil quality (Hossain et al., 2014).The total phosphorus found in soils collected from study areas was estimated between $51.2-115.4 \mathrm{~kg} / \mathrm{ha}$ (Table 1).

Potassium plays an important role in protein synthesis and maintaining water balance in plant (Hossain et al., 2014). In this study, potassium was reported in range of $378-756 \mathrm{~kg} / \mathrm{ha}$ and it was found higher than the Indian Standard as shown in Table.1. HaqMidrar (2004) reported NPK values as 21.58, 8.39 and 95.22 $\mathrm{mg} \mathrm{kg}^{-1}$ respectively upto $20 \mathrm{~cm}$ soil depth (contaminated) while $19.54,6.39$ and $73.72 \mathrm{mg} \mathrm{kg}^{-1}$ respectively at $20-40 \mathrm{~cm}$ soil depth (standard soil from sub-surface).

\subsection{Calcium and Manganese}

Calcium was estimated up-to $0.05 \mathrm{meq} / 100 \mathrm{~g}$ higher in all the samples while Manganese in Site S1 showed higher concentration as compared with standard values. Similar results were reported by Libutti et al. (2018).

Results of current study are in agreement with the findings of Trivedi \& Verma (2016) who have reported higher concentration 
of sodium and potassium with moderate accumulation of available potassium in soil near textile effluent outlets along Jojari River. According to Maheswari (2013), around $120 \mathrm{~km}$ surrounding of the Bandi River became barren due to textile effluent discharge. Similarly, Shrivastava \& Koka (2014) assessed the effect of textile effluent discharge in the area near to Bandi River and found similar results. Dutta \& Singh (2014, 2015) reported that soil of Pali region became hard and barren due to excess use of textile effluent in irrigation. The condition of soil in Jodhpur and Balotra region is badly affected by the discharge of industrial effluents which gets mixed up in the Jojari and Luni Rivers at initial stages. Therefore, the wastewater used for irrigation decreases the soil properties. Agriculture soils of the above regions were found to become barren and not suitable for vegetation. Similarly, Jhamaria \& Bhatnagar (2015) found higher $\mathrm{pH}$, EC and organic carbon percentage at wastewater irrigated sites as compared to that irrigated with bore well water. Krishna \& Govil (2004) also studied soil samples collected from a depth of $5-15 \mathrm{~cm}$ around industrial area of Pali district, Rajasthan and found higher concentration of heavy metals like lead, chromium, copper. They also reported cadmium accumulation in study area soil and it was above safe limits.

\section{Conclusion}

The higher concentration of industrial effluents that mixed up in the soil disturbs negatively the overall physico-chemical properties. The textile wastewater should not directly used for irrigation purpose. Therefore some suitable approach to detoxify wastewater must be applied for cost effective and economically healthier crop yield. The present study highlights that textile discharges mixed up with water and turn it into misfit for irrigation. Moreover, organic pollutants and industrial effluents adversely affects the soil quality. The inherent soil parameters such as nitrogen, potassium, calcium, manganese, phosphorous, organic carbon are found to be in higher magnitudes that make them toxic. Therefore the overall soil fertility decreases. Findings of this research study reveal an intimating scenario for the farmers who are mostly dependent on the agriculture for their livelihoods, and frequently use contaminated industrial wastewater for irrigation.

\section{Acknowledgements}

Authors pay their extreme gratitude to President, DEAN of Mody University and Rajasthan State Pollution Control Board laboratory for providing necessary experimental facilities.

\section{Conflict of interest}

Author hereby declares that they have no conflict of interest.

\section{References}

Anjaneyulu Y, Sreedhara Chary N, Samuel DSR (2005) Decolorization of industrial effluents available methods and emerging Technologies- a review. Reviews in Environmental Science and Bio/Technology, 4:245-273.

Chhonkar PK, Datta SP, Joshi HC, Pathak H (2000) Impact of industrial effluents on soil health and agriculture-Indian experience: part II- Tannery and Textile Industrial Effluents. Journal of Scientific and Industrial Research 59:446-456.

Dutta S, Singh S (2014) Assessment of ground water and surface water quality around industrial area affected by textile dyeing and printing effluents, Pali, Rajasthan, India. Journal of Environmental Research and Development 8: 574.

Dutta S, Singh S (2015) Seasonal variation in different physicochemical characteristics in ground water quality of Pali industrial area, Rajasthan, India. International Journal of Research in Pharmaceutical Sciences 5: $25-29$.

Edori OS, Iyama WA (2017) Assessment of Physico-chemical Parameters of Soils from Selected Abattoirs in Port Harcourt, Rivers State, Nigeria. Journal of Environmental Analytical Chemistry 4: 194.

HaqMidrar UI (2004) NPK Status in Effluent Irrigated Soils of Some Selected Sites of NWFP. International Journal of Agriculture and Biology 6: 264-267.

Hossain AK, Marine SS, Raihan F, Redowan M, MiahMd D (2014) Textile effluents changes physiochemical parameters of water and soil: Threat for agriculture. African Journal of Agronomy 2: 219-223.

Jhamaria C, Bhatnagar M (2015) Accumulation of heavy metals in soil due to wastewater application. International Journal of Science and Research 4: 689-690.

Jolly YN, Islam A, Mustafa AI (2012) Impact of Dyeing Industry effluent on soil and crop. Universal Journal of Environmental Research and Technology 2: 560-568.

Kaur V, Sharma G (2014) Effect of industrial effluents on soil characteristics-A review. International Journal in Advances in Engineering Science and Technology 3: 201-207.

Krishna AK, Govil PK (2004) Heavy metal contamination of soil around Pali industrial area, Rajasthan, India. Environmental Geography 47: 38-44.

Libutti A, Gattaa G, Gagliardia A,Vergineb P (2018) Agroindustrial wastewater reuse for irrigation of a vegetable crop 
succession under Mediterranean conditions. Agricultural Water Management 196: 1-14.

Maheswari R (2013) Toxic troubles: effluents being dumped in Bandi River, Pali, Rajasthan. Bulletin of Environment, Pharmacology and Life Sciences 2: 01.

Meena LR, Nama P (2016) Study on physico-chemical analysis of textile effluents in Balotra and Pali, Western Rajasthan. Indian Streams Research Journal 6: 1-7.

Meena RS, Mathur AK (2017) Available Micronutrients in Relation to Soil Properties of Ghatol Tehsil, Banswara District of Rajasthan, India. International Journal of Current Microbiology and Applied Sciences 6: 102-108.
Okoye COB, Agbo KE (2011) Dispersion Pattern of Trace Metals In Soils Surrounding Solid Waste Dumps In Nsukka. Journal of Chemical Society of Nigeria 36: 112-119.

Reeuwijk L van (2002) Procedures for soil analysis, International Soil Reference and Information Centre, FAO, Wageningen. $6^{\text {th }}$ Edition, 6-1.

Srivastava M, Koka V (2014) Assessment of textile effluent discharge on soil quality in Pali district of Rajasthan. Asian Journal of Home Science 9: 232-236.

Trivedi R, Verma A (2016) Threat to Aquatic Biodiversity of Arid Regions: A review on Dyeing units in Rajasthan. In: Bamniya BR, Gadi BR (Eds.) Environmental Impact on Biodiversity. Today \& Tomorrow's Printers and Publishers, New Delhi. Pp.21-40. 